\title{
Dendrogeomorphogical assessment of snow avalanche activity in Parâng Mountains
}

\author{
Flaviu Meseșan, Olimpiu Pop, Ionela Gavrilă, Cosmin Timofte \\ Babeș Bolyai University, Faculty of Geography \\ Laboratory of Dendrochronology \\ Cluj-Napoca, Romania
}

\begin{abstract}
In the alpine area of the Romanian Carpathians in general and Parâng Mountains in particular, snow avalanches play an important role in the landscape and ecosystems dynamics. When the snow masses reach the treeline, they are stopped by forests and cause severe disturbances or even death to the trees. If snow avalanches affect repeatedly the same forest area, an avalanche path takes shape. Inside it, the snow avalanche activity is clearly witnessed by forest vegetation. The trees record in their rings signs of past avalanche activity. In particular forest areas, these are the only avalanche event records that can be investigated in order to improve the knowledge regarding past avalanches. Dendrogeomorphology proved to be the most reliable tool for this scope, allowing yearly reconstructions of avalanche frequency and spatial extension. The present study aims to accomplish tree ring reconstruction of snow avalanche in two avalanche paths located on the southern slope of Parâng Mountains, in the proximity of Păpușa Peak (2135 $\mathrm{m}$ a.s.l.), one facing southwest and the other facing southeast. The first mentioned avalanche path is crossed by Transalpina road. Rânca ski resort is placed on a convex slope between these avalanche paths. In the southwestern path, 58 Norway spruces (Picea abies (L.) Karst.) showing severe disturbances caused by snow avalanches were sampled. In the southeastern path, other 52 spruces were sampled. Based on the sampled trees growth disturbances (e.g. scars, tangential rows of traumatic resin ducts, compression wood, growth suppression), the avalanche event chronology was developed for each avalanche path. Then, using a new GIS-based approach, the snow avalanche frequency and return periods were calculated and mapped. The results of this study can contribute to avalanche hazard mapping in the study area and should prevent freeride skiers regarding the snow avalanche risk on southern slopes of Păpușa Peak.
\end{abstract}

Keywords- snow avalanche; Parâng Mountains; denndrogeomorphology

\section{INTRODUCTION}

In the alpine areas of the Carpathians, the snow avalanches are common geomorphic processes. Along occasional damage caused to existing infrastructure (roads, sky areas, buildings, hiking trails, etc.) this processes cause also loss of human lives.

During their descent, the snow avalanches are channeled by topographic features like gullies or valleys until they pass the treeline, causing a significant damage upon forest areas. Repeated avalanche events, even with yearly frequency, may affect the same forest areas. In this case, the forest cannot recover to the state before the event until subsequent event occurs and produces additional damage.

A stripe without mature trees takes shape in the mature forest, downslope from the treeline. In few years, this area is colonized by young coniferous trees or shrubs. The avalanche path includes this stripe but also the starting zone located above treeline and the track placed partially above treeline, partially below it.

The young trees located inside the avalanche path, but also some of the mature trees from the border of the path usually present visible growth disturbances related to the mechanical impact of the avalanches: scars, titled stems, broken tops, broken branches. Based on these, the year(s) when the impact occurred can be identified using geomorphic methods. Such reconstructions of snow avalanche activity were successfully performed in the western part of Parâng Mountains [1], in Făgăraș Mountains [2], in Alps Mountains [3] and other mountain areas worlwide.

In the Romanian Carpathians, the snow avalanche activity is poorly documented. Usually, the recorded avalanche events are the most severe ones, that damaged significant forest areas. In this cases, cleaning up the affected areas was required in order to protect the living trees from fungal infections or from insect outbreaks and also to use the timber from the broken trees.

The avalanche triggering risk in the proximity of Păpușa Peak is confirmed by Cătălina Săndulache in her $\mathrm{PhD}$ thesis [4]. A fatality occured because of snow avalanches near Păpușa Peak is mentioned. The occurence year is not mentioned.

\section{STUDY AREA}

The study area for the present paper consists in two avalanche paths located in the proximity of Păpușa Peak, in the central part of Parâng Mountains, belonging to Southern Carpathians, Romania (fig. 1). One of the avalanche paths is located on the southwestern slope of Păpuşa peak, in a valley called Romanul. 


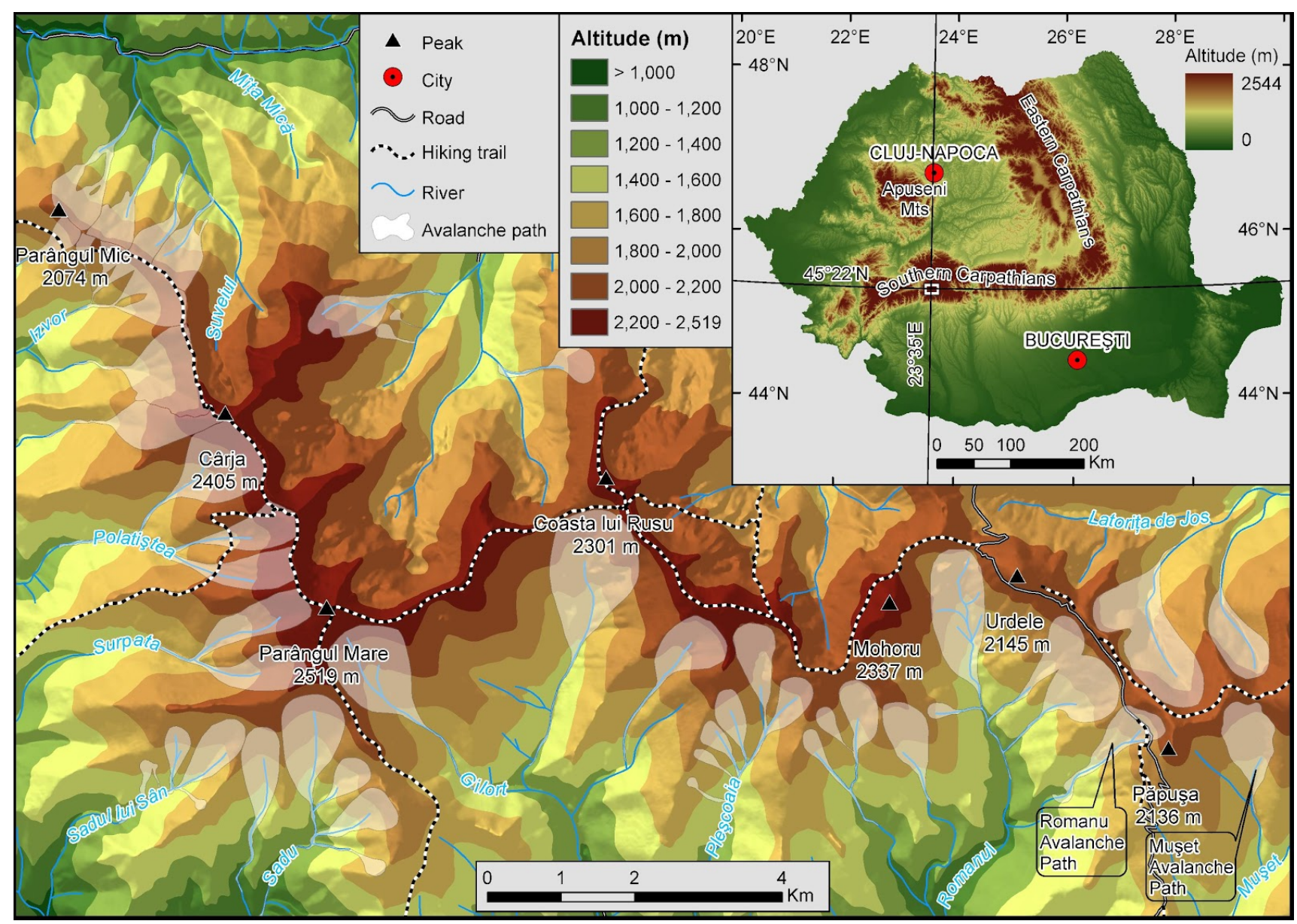

Fig. 1. Study area location.

The start zone reaches the altitude of $2100 \mathrm{~m}$ a.s.l. and the runout zone descends below $1400 \mathrm{~m}$ a.s.l. In the track zone, the valley is deep and the slopes are very steep, especially the western slope. Because of this, the avalanche path can be classified as a typically confined avalanche path. The bottom of the valley and the eastern slope are populated by shrubs and small coniferous trees. The surface of the path is approximately $0.5 \mathrm{~km}^{2}$ and its maximum length is around $1.7 \mathrm{~km}$. In the starting zone, the avalanche path is crossed by Transalpina road. Its status is still road in construction. No avalanche protection technical measures were implemented to protect it from snow avalanches. Excepting the segment from Novaci to Rânca (below $1900 \mathrm{~m}$ at the south of this path), the road is closed during the winter season.

The second avalanche path is located at the east of Păpușa Peak, in the superior basin of a valley called Mușet. It originates at the south of the main ridge, in an incipient glacial cirque, around $2100 \mathrm{~m}$ a.s.l. The runout zone is placed below $1700 \mathrm{~m}$ a.s.l., where the slope is less steep. Around this altitude the snow masses reach the treeline. A quite compact group containing trees with various ages, was affected repeatedly by snow avalanches. The surface of this path is also approximately $0.5 \mathrm{~km}^{2}$, but it has a rounder shape compared with the previous one, with a maximum length around $1.3 \mathrm{~km}$.

\section{METHODS}

The working phases covered in this study followed the classical approaches performed in tree-ring reconstruction of avalanche activity: tree sampling, samples preparing and analyzing, snow avalanche reconstruction. [3, 5].

In the field, the trees shoving severe growth disturbances associated with avalanche activity were sampled using Pressler borers or a saw. In Romanul valley avalanche path, 105 increment cores and 23 cross sections were gathered from 58 trees. In Muşet valley avalanche path, 37 increment cores and 38 cross sections were gathered from 57 trees. The increment cores were glued on spruce slats and air dried along with cross sections. Then all of them were finely sanded.

The width of the tree rings was measured using a strere omicroscope with a moving table (LINTAB 5 workstation) connected to a computer with TSAPWin Professional 0.55 software. The growth anomalies were noted in a Microsoft Excel table and semiautomatically centralized. For every year when multiple growth disturbances were recorded, an index value was calcultated according to [6]. The avalanche event years were established according to the criteria sugested by [7]. As an additional criterion to consider a year as avalanche event year, the value of Shroder's index must be higher than $10 \%$.

A point shapefile representing the location of the sampled trees was created for every avalanche path from the GPS points collected in the field. For every reconstructed avalanche event, the points were classified in disturbed trees for trees presenting growth distubances related to the avalanche event and undisturbed trees for the rest of the points. These data were used to map the spatial extension of every avalanche year. Further usage was to 
calculate the number of the avalanche events that affected every point of the avalanche path.

\section{RESULTS}

The analysis of the collected samples revealed 11 avalanche event years in Romanul valley avalanche path. At leat one of the sampled trees presented a scar in each of this years. Without taking into consideration the 1895 avalanche event, 10 avalanche events took place in 27 years.

Significant differences can be observed between the spatial extension of various avalanches. Some of them affected the entire avalanche path (for example the avalanche occurred in 2004-2005 winter). Other avalanches affected only the sampled trees located near the treeline (like the avalanche occurred in 1997-1998 winter).

In the Mușet valley avalanche path, 10 avalanche events were identified. The length of the avalanche chronology reconstructed in this avalanche path is 41 years.

Because all the sampled trees are grouped in the runout zone of the avalanche path, it was not possible to identify many sectors of the path affected by a different number of avalanche events. Almost the entire path affected by all the reconstructed avalanches.

\section{CONCLUSIONS}

The snow avalanche activity reconstructed in both avalanche path confirms that in this area snow avalanches constitutes a significant risk that must be taken into consideration when planning the infrastructure development or the routes for free ride skiing.

\section{REFERENCES}

[1] O. T. Pop, I. G. Gavrilă, G. Roșian, F. Meseșan, A. Decaulne, I. H. Holobâcă, and T. Anghel, "A century-long snow avalanche chronology reconstructed from tree-rings in Parâng Mountains (Southern Carpathians, Romania).," Quaternary International, vol. 415, pp. 230-240, 2016.

[2] P. Chiroiu, M. Stoffel, A. Onaca, and P. Urdea, "Testing dendrogeomorphic approaches and thresholds to reconstruct snow avalanche activity in the Făgăraş Mountains (Romanian Carpathians)," Quaternary Geochronology, vol. 27, pp. 1-10, 2015.

[3] C. Corona, G. Rovéra, J. Lopez Saez, M. Stoffel, and P. Perfettini, "Spatio-temporal reconstruction of snow avalanche activity using tree rings: Pierres Jean Jeanne avalanche talus, Massif de l'Oisans, France," Catena, vol. 83, no. 2, pp. 107-118, 2010.

[4] C. Săndulache, "Hazarde și riscuri naturale în Munții Parâng", București: PhD Thesis, Universitatea din București, 2009.

[5] M. Stoffel, D. R. Butler, and C. Corona, "Mass movements and tree rings: A guide to dendrogeomorphic field sampling and dating," Geomorphology, vol. 200, pp. 106-120, 2013.

[6] J. F. Shroder, "Dendrogeomorphological analysis of mass movement on Table Cliffs Plateau, Utah," Quaternary Research, vol. 9, no. 2, pp. 168-185, 1978.

[7] M. Stoffel and C. Corona, "Dendroecological dating of geomorphic disturbance in trees," Tree-Ring Research, vol. 70, no. 1, pp. 3-20, 2014. 